\title{
Smallholder Farmers in the Speciality Coffee Industry: Opportunities, Constraints and the Businesses that are Making it Possible
}

\author{
Inma Borrella, Carlos Mataix and Ruth Carrasco-Gallego
}

\begin{abstract}
Coffee has traditionally been a commodity product sold in a highly competitive and saturated global market. This lack of product differentiation has made coffee farmers very vulnerable to fluctuating prices. During the last decade, the coffee industry is undergoing a process of decommoditisation, offering an opportunity for farmers to differentiate their coffee in terms of sustainability and quality and to commercialise it more directly. However, smallholder farmers face productivity and transactional constraints that inhibit them from accessing these higher-value market segments. Intermediaries are needed to connect them with this new market. In this article, we present a cross-case study analysis of three 'connective businesses' that are facilitating direct trade relationships between smallholder farmers and speciality coffee roasters.
\end{abstract}

\section{Introduction}

Coffee is one of the most important agricultural commodities traded in international markets, in terms of both volume and value. In crop year 2012/13, 145 million bags ${ }^{1}$ of coffee were produced in countries of Asia (32 per cent), Africa (11 per cent) and Latin America (57 per cent) and the total value of the coffee industry was estimated at around US $\$ 173.4$ billion $^{2}$ (International Coffee Organization 2014a, 2014b). On the consumer side, the major importers are industrialised countries, in particular the USA, Europe and Japan.

Therefore, the income and wealth disparities between coffee-exporting nations and the main importing nations are substantial. While coffee imports and prices are a minor matter for the large coffee-importing countries, they have exceptional importance in the economies of many producing countries, which are largely dependent upon this commodity for their export earnings.

Coffee production is closely related to rural development and poverty. The International Coffee Organization estimates that there are 25 million coffee producers worldwide, and most of them are smallholder farmers who depend directly on coffee for their livelihoods. Thus, coffee provides income opportunities in the rural areas of many tropical countries. When properly managed, coffee plantations can reduce environmental degradation and provide job opportunities. However, coffee farmers are currently facing great challenges to achieve social, environmental and economic sustainability of their business.

First of all, the volatility of the coffee market has been a continual problem for decades. This price uncertainty may hinder appropriate decisionmaking regarding resource allocation and planning. And, while coffee prices go up and down, the main costs of production - labour, fertilisers and phytosanitary products - are rising in all countries. ${ }^{4}$ On the environmental side, pests and diseases continue to ravage coffee plantations: the recent leaf rust plague in Central America has been especially virulent; ${ }^{5}$ poor farm management has led to deforestation, soil degradation and water pollution; and climate change might alter agroclimatic conditions in traditional coffee-producing areas. Furthermore, 


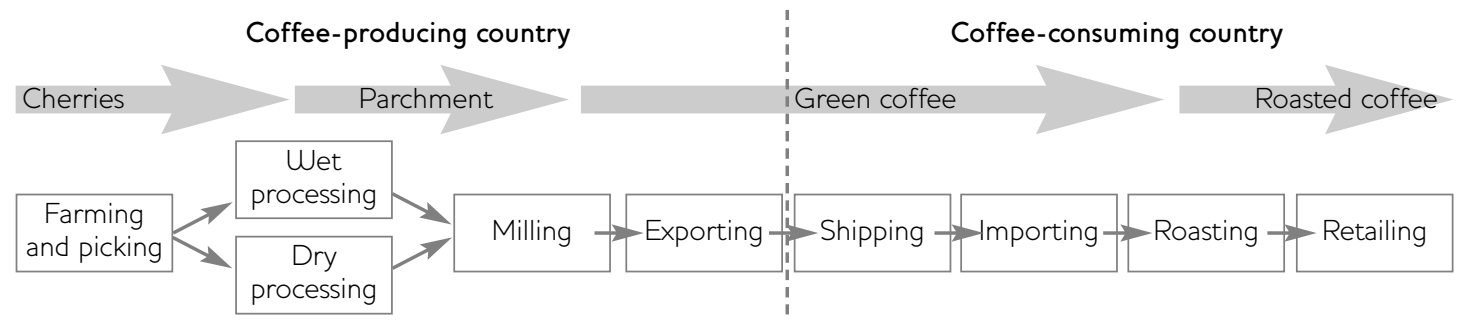

Source Authors' own.

access to commercial information, credit and diversification opportunities are often beyond reach for smallholder farmers, undermining their ability to recover from economic and environmental shocks.

Development actors in coffee-producing countries - sometimes in collaboration with governments have tried to alleviate the difficulties encountered by smallholder coffee farmers in making their business flourish. Their goal is usually to improve development outcomes in coffee-producing areas, such as attenuating rural poverty and vulnerability, sustaining rural population livelihoods and reducing migration to urban areas, and improving the environmental sustainability of delicate ecosystems. However, these public efforts need to be combined with consistent purchasing policies and practices of coffee-buying companies, who have determined the course of the industry since its liberalisation in 1990.

To reduce the poverty and vulnerability of coffee smallholders, it is necessary to pay coffee prices that cover costs of production and living costs and to facilitate farmers' access to resources mainly credit, market information and agricultural inputs. The coffee industry has proven to be a highly lucrative one; however, it is characterised by an uneven distribution of value and risk among the actors involved. Coffee supply chains are buyer-driven commodity chains in which the lead firms - importers and roasters - govern the chain in a hands-off way, maintain the opacity and capture most of the gains.

Therefore, to improve smallholders' opportunities, it is necessary to challenge the way coffee supply chains are governed.

Nowadays, with the global production of coffee reaching its saturation point and consumption continuously growing, ${ }^{6}$ some coffee-buying companies are changing their way of doing business to differentiate their products in an increasingly saturated market. In order to ensure a sustainable, stable and varied supply of coffee in the long term and satisfy consumers' demand for sustainable coffee, they are applying two different - though complementary - strategies: sustainability certifications (hands-off governance) and direct trade (hands-on governance). The way sustainability certifications work as governance mechanisms and their impacts on coffee producers have been the subject of study of countless reports and articles. However, direct trade is a relatively new approach popularised by the speciality coffee industry. It is based on building direct and transparent relationships among coffee roasters and producers. Direct trade has barely been addressed in the academic literature; we thereby set out to close this gap.

The need for greater coordination and control in high-quality coffee supply chains, the concerns about the social and environmental challenges faced by farmers, and the willingness to discover rare types of beans in remote coffee-producing areas, have driven speciality coffee roasters to approach the source of coffee and develop closer relationships with farmers. This new way of trading coffee in which roasters and farmers know each other, communicate directly, close deals and seek for long-term relationships is called 'direct trade'. This approach is essentially different from that of the mainstream coffee trade, in which roasters buy coffee from an importer and rarely have any contact with suppliers in the producing country.

When coffee farmers are able to connect with the end market in a more direct and transparent 
Figure 2 The coffee supply funnel
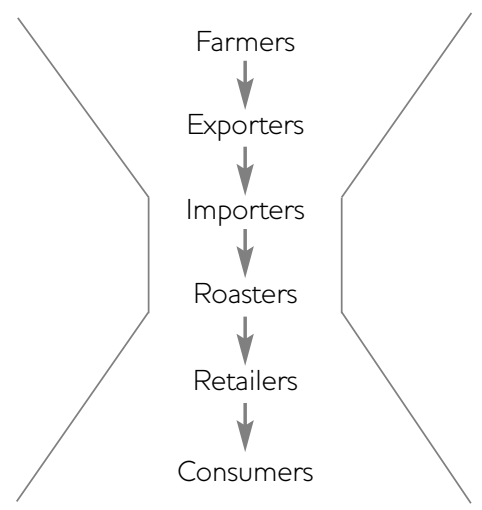

Source Authors' own (inspired by Gereffi and Lee 2012).

way, new opportunities arise. It allows them to better understand market requirements, adapt their products to the clients' needs and achieve a competitive advantage by offering a differentiated product. But selling to roasters in a direct way is very difficult for vulnerable smallholders in developing countries.

This article presents a cross-case analysis of three 'connective businesses', expert trading businesses that work in the speciality coffee industry segment facilitating direct trade connections between roasters and smallholder farmers. The authors first carried out secondary research work on coffee connective business, which was enriched and contrasted later on with two weeks of fieldwork in East Africa (July 2013) compiling primary information about these businesses and their suppliers. Primary data collection included the following methods: direct observation of connective businesses' work in the office and in the field, informal conversations with staff, visits to smallholder farms and coffee-processing facilities, and semi-structured interviews with their CEOs and coffee-purchasing managers.

The remainder of the article is organised as follows. In Section 2, we introduce the mainstream global supply chain of coffee and explain two trends that are bringing this product out of the commodity status, namely, differentiation by sustainability and by quality. The new speciality coffee industry requires a different approach to supply chain relationships, such as direct trade, that opens up a space for new actors in the coffee trade outlook. Those new actors, the so-called connective businesses are introduced in Section 3, where we also develop the three case studies that result from the research presented in this article. The crossanalysis of the case studies enabled us to obtain some initial insights, developed in Section 4, on how connective businesses are creating shared value with low-income coffee producers. Finally, the conclusions of this study are summarised in Section 5.

\section{Decommoditising coffee: from a soft commodity to a speciality product}

Coffee is a soft commodity ${ }^{7}$ like tobacco, cotton, sugar, rubber, tea and cocoa. These agrocommodities remain the main strand linking the world's rural poor with global product markets (Gibbon 2001).

In the mainstream, commodity coffee supply chains (Figure 1) are buyer-driven chains (Ponte 2002a) in which most of the power remains in the hands of large coffee roasters that control a huge market share. Almost 45 per cent of green coffee imports is purchased by the five largest roasters: Philip Morris, Nestlé, Sara Lee, Procter \& Gamble and Tchibo (Panhuysen and van Reenen 2012). These roasters tend to rely on multinational commodity-trading companies such as Volcafé, Neumann and ECOM - for their supply of green coffee. Coffee is imported in bulk, bought and processed by roasters, and sold by retailers.

As depicted in Figure 2, roasters have maintained a dominant position through the effective management of asymmetry of information on quality. Roasters buy green coffee from traders with complete quality information, and after roasting and blending it, they sell it under a brand name. Little or no information about quality and origin is disclosed to the end consumer. Therefore, coffee is differentiated by brand, not by its intrinsic attributes. In these mainstream coffee chains, roasters, traders and retailers are the actors capturing most of the value, while little of it remains in the producing country.

However, the coffee market outlook is changing and coffee is not such a homogeneous product any more. During the last decades, some segments of the coffee sector have suffered a process of decommoditisation (Fitter and Kaplinsky 2001) due to several factors: an increasing sensitivity towards sustainability 


\begin{tabular}{|c|c|c|c|c|}
\hline \multicolumn{3}{|c|}{ First wave } & Second wave & Third wave \\
\hline 1930 & & 1960 & 1990 & present \\
\hline & $\begin{array}{l}\text { Bulk production and mass } \\
\text { consumption of coffee }\end{array}$ & & $\begin{array}{l}\text { The speciality coffee segment } \\
\text { emerges }\end{array}$ & $\begin{array}{l}\text { Coffee becomes an artisinal } \\
\text { product }\end{array}$ \\
\hline & $\begin{array}{l}\text { Large food corporations control } \\
\text { the coffee market }\end{array}$ & & $\begin{array}{l}\text { Coffee is differentiated by } \\
\text { quality }\end{array}$ & $\begin{array}{l}\text { Coffee is differentiated by origin, } \\
\text { taste, roast, brewing method... }\end{array}$ \\
\hline & & & $\begin{array}{l}\text { American coffee roasters Peet's } \\
\text { and Starbucks lead this wave }\end{array}$ & $\begin{array}{l}\text { A new generation of local micro- } \\
\text { roasters popularise 'direct trade' }\end{array}$ \\
\hline
\end{tabular}

Source Authors' own.

issues, a greater awareness among consumers about the challenges faced by coffee producers, a growth of demand for quality coffee from specific origins, and the creation of new ways of commercialising coffee (capsules, ready-to-drink, speciality coffee shop chains). Therefore, the main decommoditisation trends in the coffee industry are driven by sustainability and quality demands.

Consumers' sensitivity about sustainability issues related to coffee production has been growing during the last decades, fostered by the Fair Trade movement (Kilian et al. 2006; MckoneSweet 2004). This demand for sustainable coffee has led to the creation of certifications meant to connect producers and consumers through a label that represents both fairer trade conditions and a more sustainable production. However, while these certifications are useful for differentiating a product in the end market as a 'credence good' (Reardon et al. 2001), they do not essentially challenge the way supply chains work. Certified coffee supply chains can be governed in a hands-off way by roasters, who just need to specify which kind of coffee and certification they want to buy and acquire it from traders. Certifications' sustainability requirements only apply at the farm level, and the cost of implementing and maintaining the certification is usually borne by the producers themselves, marginalising the poorest farmers ${ }^{8}$ who lack the knowledge and resources to gain the certification. Besides, there is currently a large gap between certified coffee volumes available and actually purchased (Potts et al. 2014).

Aside from sustainability, the other attribute that is bringing coffee out of commodity status is quality (Ponte 2002b). Speciality coffee refers both to whole bean sales and to coffee beverages sold in coffee bars and cafes. The range includes higher quality coffees, both single origin and blends, unconventional coffees such as flavoured coffees and coffees with an unusual background or story behind them. Speciality coffee is estimated to represent around 10 per cent of world consumption and it is the fastest growing segment in mature coffee markets (International Trade Centre 2011).

The coffee industry has gone through different phases - or 'waves' - characterised by the quality of the coffee commercialised and the information disclosed about it (Figure 3). Currently, the Third Wave of coffee wants to go beyond the differentiation by quality and transform coffee into an artisanal product such as wine. To do so, all stages of the supply chain have to be improved: from growing to harvesting, processing, trading, roasting and brewing.

Third Wave coffee roasters are making great efforts - and investments - to educate consumers to understand coffee as a speciality beverage, such as wine or beer, with its wide variety of flavours and aromas and different brewing techniques. They are pushing speciality coffee into the market by organising events, promotions, training retailers, providing coffee machinery and even vertically integrating themselves towards the retail side.

On the upstream part of the supply chain, Third Wave coffee roasters buy coffee directly from the farmers, establishing direct trade relationships. Direct communication allows further exchange of knowledge between buyer and supplier, fosters 


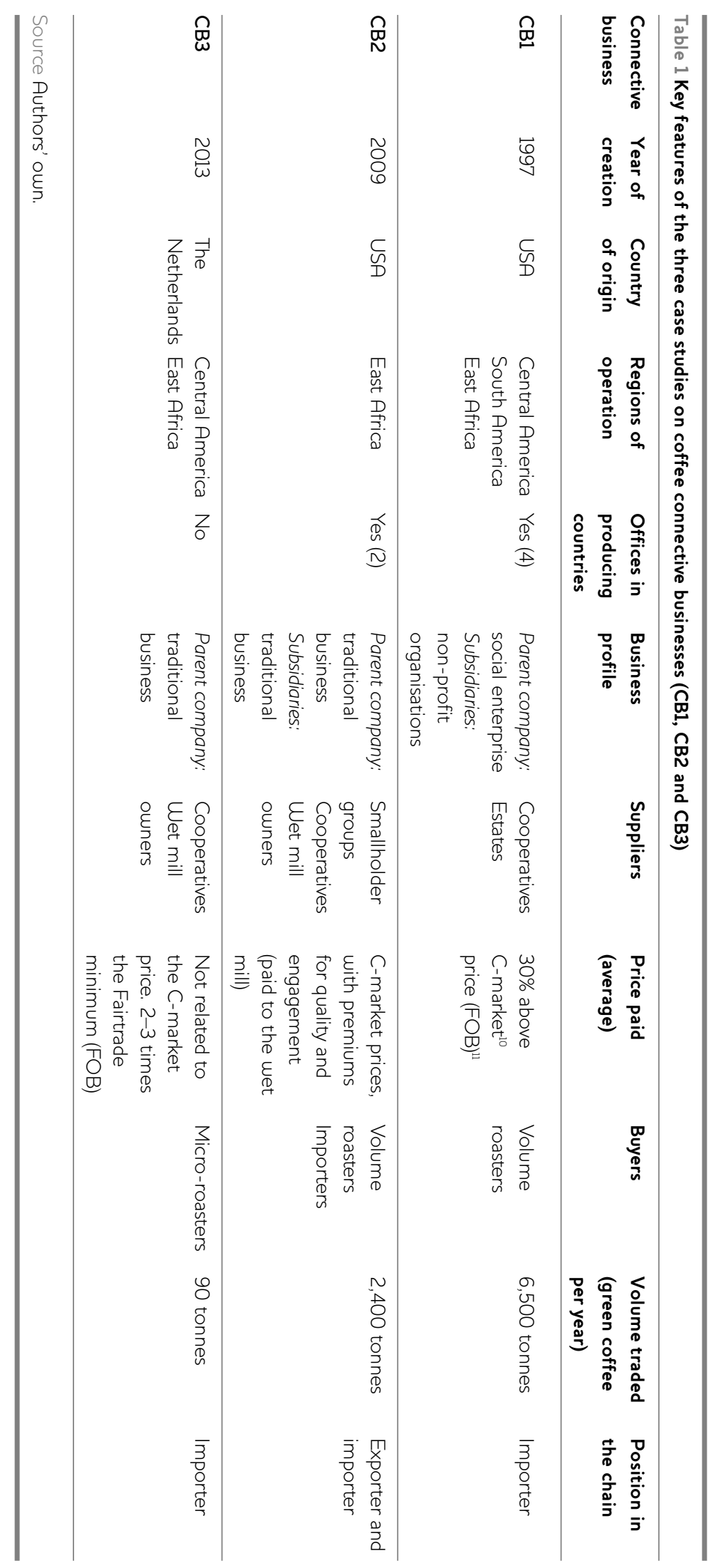




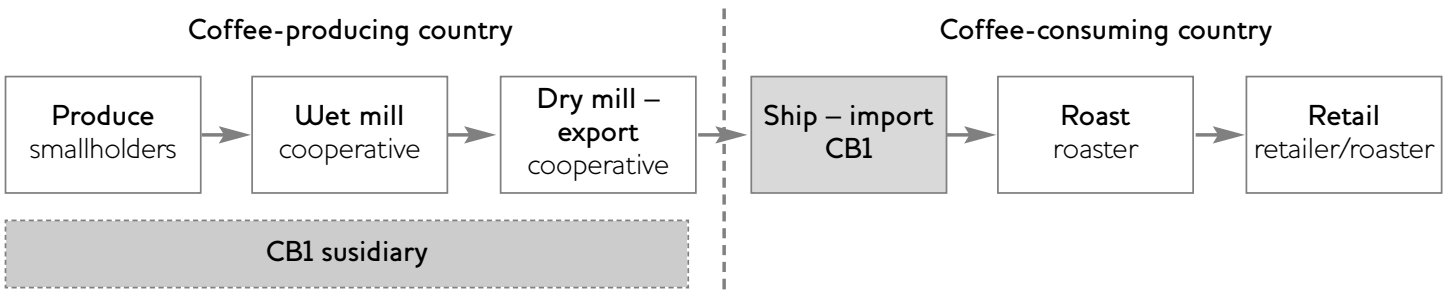

Source Authors' own.

a better understanding of expectations and limitations, and helps to build relationships and partnerships that go beyond mere market transactions. Furthermore, in this new segment of the coffee market retail prices are considerably higher, allowing roasters and farmers to negotiate contracts on the fringes of the prices established by the financial markets. This direct trade approach is challenging the status quo of existing coffee supply chains. As Raynolds (2009) suggests, quality-driven coffee buyers can create new types of partnerships via collaborative engagements, and improvements in quality might increase farmers' ability to define their position in global markets.

The biggest market for speciality coffee is the USA, currently estimated at $\$ 25.3$ billion (Speciality Coffee Association of America 2014). The pioneers of the Third Wave coffee movement are considered to be Intelligentsia, Counter Culture and Stumptown; American roasters with a volume of sales of around two million pounds (in weight) of coffee per year each. The Third Wave coffee philosophy is spreading fast in the USA and other mature markets such as Europe, South Africa and Japan. Nevertheless, it is difficult to estimate its dimension because it is formed by a wide global network of micro-roasters.

\section{3 'Connective businesses': the invisible actors behind direct trade}

Direct trade does not have a unique standardised definition and the concept is often misunderstood by consumers and sometimes misused by coffee industry actors. Direct trade entails a direct connection between a roaster and a supplier who seek to build a sustainable, longterm and mutually beneficial relationship to grow, process and market outstanding coffee. Roasters and farmers sometimes find their direct trade partners in Cup of Excellence events, ${ }^{9}$ but most commonly they have to rely on

Figure 5 CB2 supply chain

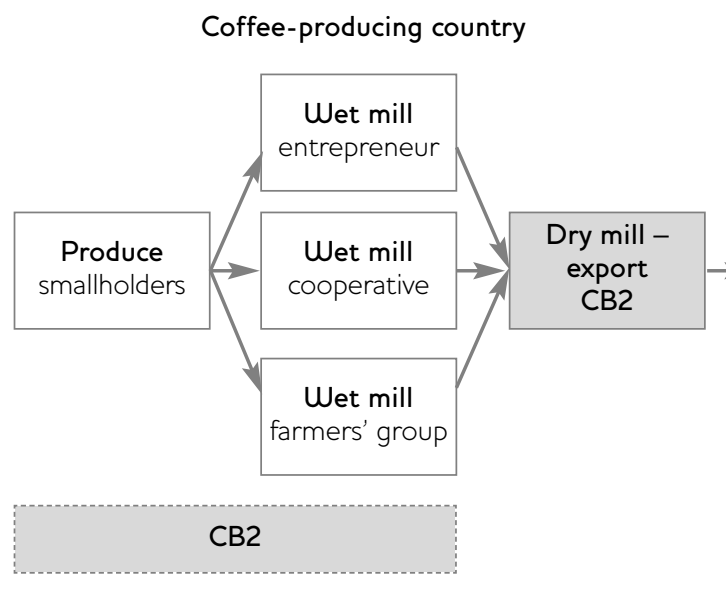



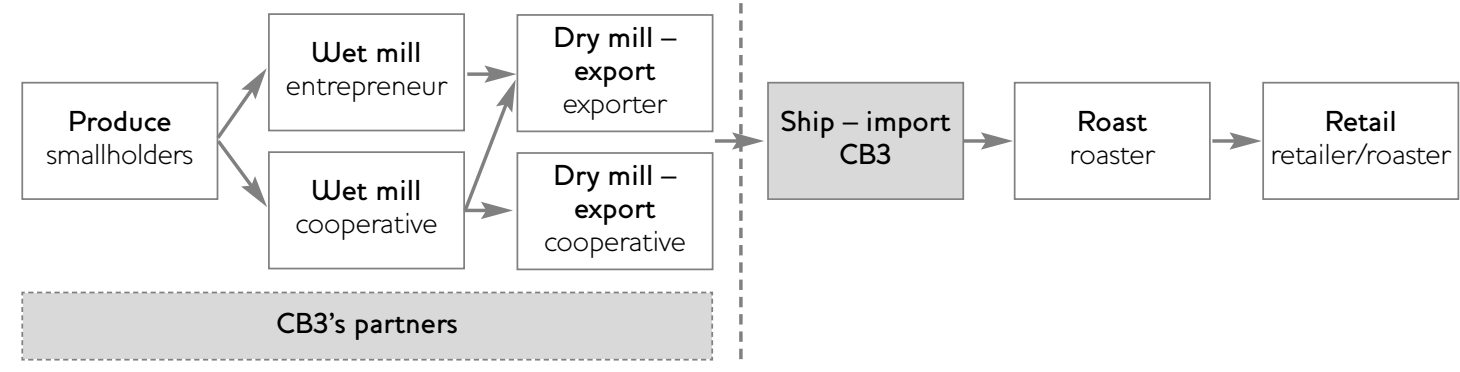

intermediaries to find the right partner and maintain the relationship. Especially when the supplier is a group of independent smallholders or a small cooperative, the role of the intermediary becomes crucial. Speciality coffee roasters have no capacity to exert the control and coordination of the upstream part of the chain that direct trade requires in these cases, and vulnerable smallholders lack the information and tools needed to access this market.

Connective businesses are companies that connect smallholders' production with speciality coffee roasters' demand. These businesses can play different roles in the supply chain but they always have a direct and close relationship with both the supplier and the buyer allowing them to do business with each other, while eliminating barriers and minimising the resources they would have to invest to do so by themselves. Most of these connective businesses play the role of importers, although some of them also act as exporters to have a greater control over the chain. Besides these functions, they carry out a wide variety of activities oriented to support the farmers and guarantee the quality and reliability of coffee deliveries.

The 'invisibility' of these businesses, which are enabling direct trade relationships, especially with the most vulnerable farmers, is surprising. Maybe due to the disparagement of the intermediaries in agro-commodities supply chains, roasters prefer to present direct trade as a direct relationship with the farmer, without mentioning the role of connective businesses. In this article, we analyse the cases of three connective businesses (CB1, CB2 and CB3) within the coffee industry. Each of them has a different business model, but their strategies are based on the same underlying principle: establishing a more solid and direct relationship model with coffee farmers in order to improve the quality and reliability of the supply. The key features of the three case studies developed in this research work are summarised in Table 1 and a graphical representation of their supply chains is depicted in Figures 4, 5 and 6.

The raison d'être of all three connective businesses that were part of the study is to facilitate direct trade between roasters and farmers. As they state in their mission declarations, they seek to: 'link community with community', 'close the gap between grower and roaster', 'create direct and transparent commercial relationships between farmers and roasters'. Nonetheless, each of those businesses has a slightly different approach to this challenge.

CB1 is considered to be the precursor of connective businesses. Created in 1997, it has been connecting farmers and Third Wave coffee roasters since then. Its main goal is to improve the livelihoods of coffee farmers in rural communities worldwide, and it is uniquely focused on speciality, ${ }^{12}$ sustainable, shade-grown, relationship-based coffee. It bets on a combination of direct trade and sustainability certification - 90 per cent of the coffee traded is Fairtrade certified - to maximise the benefit captured by farmers. The parent company, 
located in the USA, is a for-profit company certified as a B-corporation ${ }^{13}$ and it is in charge of importing the coffee and maintaining the relationship with roasters. The subsidiaries, located in Latin America and East Africa, are non-profit organisations whose functions are supporting and training farmers - 30 per cent of the company annual net income is dedicated to these activities - and realising development projects funded by third parties - roasters and other actors. CB1 mainly works with cooperatives of smallholders (95 per cent of their supply base), although a few of their suppliers are coffee estates (5 per cent of their supply base).

CB2 is a holding of three different companies: one speciality coffee roaster and two exporters. Both exporting companies are located in East Africa and sell speciality and standard quality coffee from the region in international markets. They facilitate direct trade relationships and also sell bulk green coffee to traders. CB2 is a profitbased enterprise: in the words of its founder and former CEO 'we are not do-gooders, we are capitalists'. Nevertheless, CB2 believes a forprofit company can also deliver a positive social impact. CB2 has a strong presence in producing countries with the aim to build a network of reliable suppliers. It only trades coffee produced by smallholder farmers and offers them services such as access to agricultural inputs, training and pre-harvest credit. It is the only connective business among the three presented in this article that buys the whole amount of the coffee produced by its partnering farmers, regardless of the quality grade.

CB3 is a European independent direct trade facilitator specialising in the small-volume coffee trade. It basically provides a direct trade platform - and shipping services - to connect small microroasters and coffee growers. It doesn't have offices in origin, but relies on local partners to guarantee transparency, traceability and quality assessment. CB3 employees are continuously travelling to different coffee-producing countries to meet the coffee farmers recommended by exporters, development agencies and nongovernmental organisations (NGOs). CB3 only works with producers that have already achieved a high-quality product but are having problems selling it in the speciality coffee segment, and connects them with speciality micro-roasters. To guarantee the sustainability of the business model, CB3 consolidates all the small-volume coffee orders from a region in one shipping container and later it redistributes the bags among the micro-roasters.

Therefore, connective businesses are the actors who are making direct trade relationships between speciality coffee roasters and vulnerable smallholders possible. Connective businesses profile potential partners and help them to find the best match, facilitate direct and continuous communication between buyer and supplier, ensure transparency throughout the chain, provide incentives to farmers for growing and processing better coffee, and support farmers to improve coffee quality and yield and to develop a sustainable business model. For their services, they charge a fee that is paid by the roasters.

\section{How are connective businesses creating shared value with coffee smallholders?}

Coffee smallholder farmers are part of the base of the economic pyramid. Most live in rural communities in Latin America and Africa. They make most of their cash income from coffee production, and many of them have limited access to basic goods and services. Many of them face food insecurity during some months every year and their livelihood is vulnerable to weather, drought, and political events that disrupt production.

Trading relationships between international businesses and impoverished communities have been explored by the so-called 'Base of the Pyramid' (BoP) literature, which is grounded on a proposition of mutual value creation between businesses and the world's poor (Prahalad 2005). At first, BoP scholars focused on the poor as consumers, highlighting the huge untapped potential existing in selling goods to the poor and inviting multinational corporations to get involved and develop products adapted to the needs of less affluent consumers in developing countries (Prahalad and Hammond 2002; Prahalad and Hart 2002). The idea of alleviating poverty through selling goods was based on the libertarian belief that the poor are perfectly rational consumers (Clay 2005) and it raised great controversy. Later, BoP scholars made a call for a change of focus from the poor as consumers to the poor as producers (Karnani 2007; Karnani 2011; London and Hart 2004; London 2008). Their proposition was that for the 


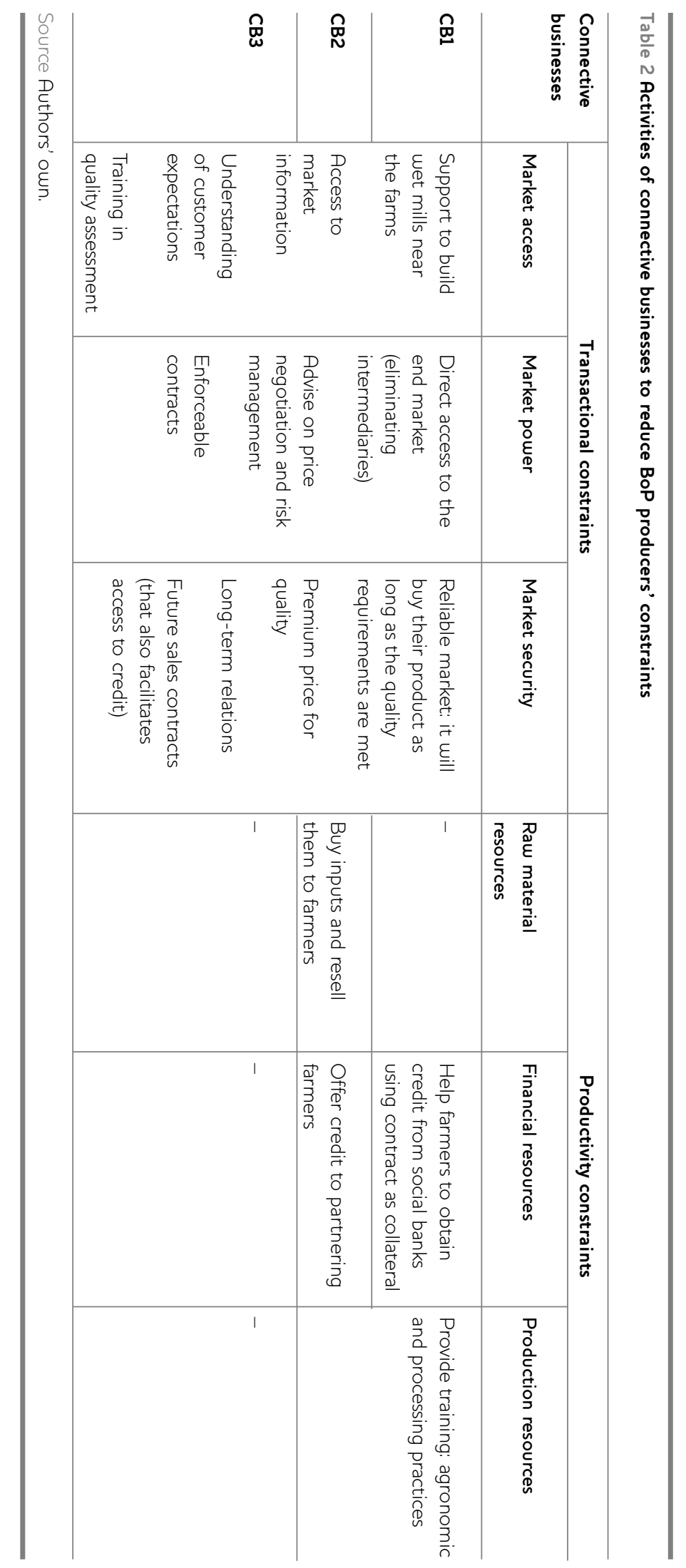


private sector to play a key role in poverty alleviation it should give priority to purchasing from the poor rather than selling to them.

However, BoP producers face many challenges incorporating their activities into formal market dynamics (Mendoza and Thelen 2008). In order to ease these constraints, BoP businesses are using different strategies: (a) addressing the unmet needs of producers to ease their incorporation into formal markets (Hall and Matos 2010; London, Anupindi and Sheth 2010); (b) improving transparency and distribution of value throughout the chain (Carter and Easton 2011; Vachon and Mao 2008); and (c) building strategic alliances with non-traditional partners - such as social enterprises and NGOs (Drayton and Budinich 2010; Sodhi and Tang 2011).

BoP literature applies the basic assumption that the incorporation of poor farmers into formal market supply chains will improve their wellbeing. Some studies suggest this could be true (Dries and Swinnen 2004; Minten, Randrianarison and Swinnen 2009). Nevertheless, Bolwig et al. (2010) point out that the impact on the poor should not be analysed only in terms of exclusion and inclusion. People may be incorporated into a supply chain, but highly marginalised or excluded. Even when people are included, this may not be on advantageous or socioeconomic terms. On the other hand, exclusion or marginality is not necessarily disadvantageous. When people lack leverage within a particular economic or social field, retreat to the margins or externality from its operations may be an advantage (du Toit 2008).

Connective businesses seek to empower vulnerable smallholder farmers and allow them to benefit from their participation in the global coffee market. They integrate shared value creation - 'create economic value in a way that also creates value for society by addressing its needs and challenges' (Porter and Kramer 2011) at the core of their business model. Their own success depends on the capacity of coffee farmers to create high-quality coffee, so improving smallholder farmers' performance would improve their own market opportunities too. This is the reason why these businesses invest a great deal of their time and resources in improving smallholders' capabilities and building partnerships with them. Connective businesses are incorporating poor smallholders into speciality coffee supply chains, offering them better opportunities to access a less volatile coffee market segment and capture more value, and they are doing this in a profitable way. Therefore, connective businesses can be considered BoP businesses that are supporting the inclusion of low-income coffee producers into a higher-valueadded market segment. To do so, connective businesses realise the three aforementioned strategies: addressing the unmet needs of producers, building strategic alliances with nontraditional partners, and improving transparency and distribution of value in the supply chain.

\subsection{Addressing the unmet needs of producers}

London et al. (2010) identified the main constraints faced by $\mathrm{BoP}$ producers to both create and capture value. They define two categories of constraints, those limiting value capture (transactional constraints) and those inhibiting value creation (productivity constraints). We have used their framework to assess how connective businesses are alleviating the barriers faced by smallholder coffee farmers to access and benefit from the speciality coffee market (Table 2).

Connective businesses are addressing coffee smallholders' transactional constraints in all their dimensions. The value captured by farmers is limited by these constraints, which are related to their difficulty to access the marketplace, their little influence in the transaction process to sell their products and the lack of access to a reliable and consistent demand to allocate their goods.

Market access constraints are due to two kinds of reasons: physical and informational ones. On the one hand, poor infrastructures in developing countries, along with the remote rural areas where smallholders usually live and difficult access to efficient public transport, makes transportation of goods - especially perishable goods - to the marketplace very challenging. Coffee cherries need to be processed within hours from the moment they are picked. In order to ease this constraint, some connective businesses ( $\mathrm{CB} 1$ and $\mathrm{CB} 2$ ) provide support and/or credit to groups of farmers to build and operate small wet mills near their farms, in which they can first process their coffee from cherry to parchment. Coffee in parchment form considerably increases its value and its storage life. On the other hand, regarding informational barriers, the lack of 
awareness of market expectations reduces the opportunities of farmers to develop a product tailored to the customers' requirements. Connective businesses share end-market information with their suppliers and also translate these market requirements - in terms of quality and other additional attributes - to facilitate farmers' understanding. ${ }^{14}$

Market power constraints are related to the influence and negotiating ability smallholders have in their market transactions. Smallholders usually are small and marginal players in the global supply chains; therefore, connective businesses play a significant role in their empowerment. Connective businesses empower their suppliers in various different ways. First of all, they connect them directly with the final market - with speciality coffee roasters eliminating other intermediaries. Connective businesses work with cooperatives, independent smallholder farmers' groups and local entrepreneurs - wet mill owners who process smallholders' coffee cherries - and advise them on price negotiation, price risk management and responsible purchasing practices. Besides, all the transactions are based on enforceable contracts that are signed and agreed by both parties.

Market security constraints are related to the instability of the final market due to price fluctuations and limited marketing options. Connective businesses facilitate smallholders' access to the speciality coffee market, a highvalue market segment that is more stable against the fluctuations of the $\mathrm{C}$-market price. Besides, speciality coffee roasters aspire to build long-term partnerships with their suppliers.

These relationships, although based on business interests, usually go beyond market transactions and lead to partnerships based on trust, a shared vision and mutual support. ${ }^{15}$

Therefore, we can conclude that connective businesses ease the three main transactional constraints identified in the framework. These businesses connect smallholder farmers to the market in a more efficient and effective way, reducing access barriers, empowering them to negotiate better, and providing more stability than the mainstream markets.

The other group of constraints mentioned in the framework are the productivity constraints.
These constraints represent barriers to value creation and are related to the difficulty of access to quality inputs, financial credit, and appropriate technologies and expertise.

CB2 is the connective business more involved in addressing productivity constraints. It buys large quantities of quality agricultural inputs and resells them - with zero profit - to its partnering farmers. It provides pre-harvest financial credit and it discounts the amount from the payment of the coffee after the harvest. It also provides training ${ }^{16}$ in agronomic practices, processing and management practices and quality management. CB1 provides training but not financial credit or inputs. CB3 does not act to ease these constraints because it is not present and continuously working with farmers in the producing country, like CB1 and CB2.

Although some connective businesses are addressing productivity constraints, they are not doing it alone. They usually combine efforts with development partners, aiming to have a multiplying effect in coffee regions.

\subsection{Building strategic alliances with non-traditional partners}

Connective businesses work with smallholder coffee farmers to improve their coffee and put it into the market. However, when the productivity constraints faced by the smallholders are too big, they collaborate with development actors to relieve them. Development actors - NGOs, development agencies - in coffee-growing regions usually focus their efforts on supporting smallholder farmers to improve their yield and access to the market, with the aim of improving the amount and stability of their income. However, the marketing part is the most challenging for development actors since it is not their field of expertise and the coffee sector is a complex and risky one.

Therefore, the collaboration between development actors and connective businesses has the potential to generate positive outcomes for all the groups involved. On the one hand, smallholder farmers receive agronomic training, access to agricultural inputs and financial support by development actors; and on the other hand, they can access a higher-value market segment thanks to the connective business. 


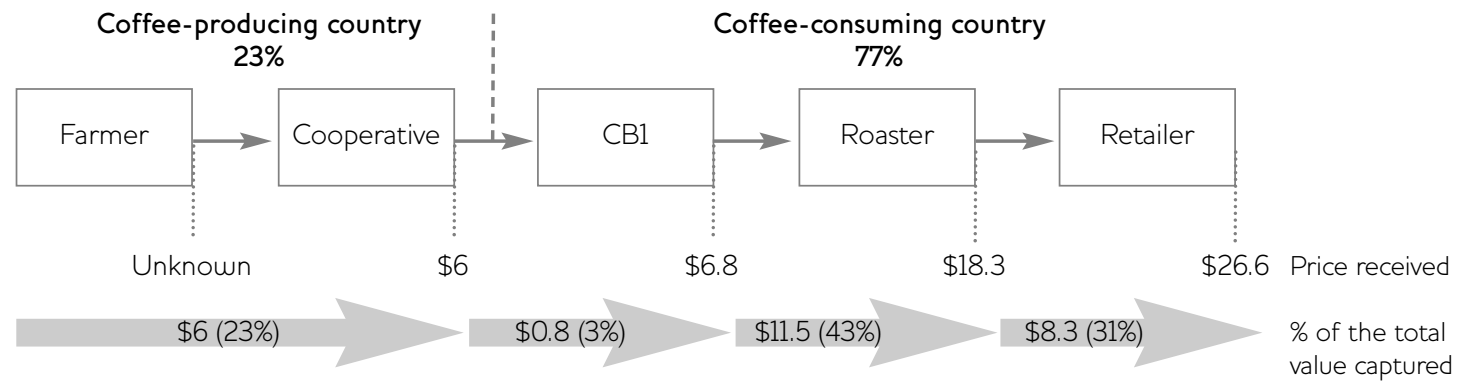

Source Authors' own.

These alliances are commonly formed between connective businesses and development actors with a focus on business and access to markets as a path for poverty alleviation, for example NGOs like Technoserve or SNV, foundations such as Progreso and international agencies such as the United States Agency for International Development (USAID).

\subsection{Improving transparency and distribution of value}

Direct trade coffee supply chains, facilitated by connective businesses, are ensuring high levels of transparency among all the actors involved in the chain. The value captured by each actor is disclosed and the supply chain is streamlined, eliminating superfluous intermediaries who were not adding value to the product. However, is this changing the way value is distributed?

We have analysed the supply chains of three speciality coffee batches, from producer to retailer, to determine the prices paid to each actor and the total value captured. The results for this analysis are presented in Figures 7, 8 and 9.
Regarding the distribution of value, in the direct trade supply chains studied, farmers and cooperatives capture between 10 and 23 per cent of the final product value. This represents an improvement from the traditional supply chains in which it is estimated that coffee producers receive only between 7 and 10 per cent of the final value (Curtis 2013). However, most of the value is still captured by roasters and retailers in developed countries, between 77 and 86 per cent.

We would like to point out that the value created in the speciality coffee value chains is much bigger than the one in the mainstream markets, resulting in a noticeable increase of income for producers. In all three cases, the Free On Board (FOB) price (see endnote 11) is larger than the minimum price settled by the Fairtrade Foundation, which is US $\$ 3.74$ per kilo of fair trade organic green coffee. The FOB prices paid in the three supply chains analysed were US\$6, US\$7 and US\$3.78 respectively.

Although we made a classical value chain analysis to understand how the value is distributed, it

Figure 8 Analysis of value distribution within CB2 supply chain

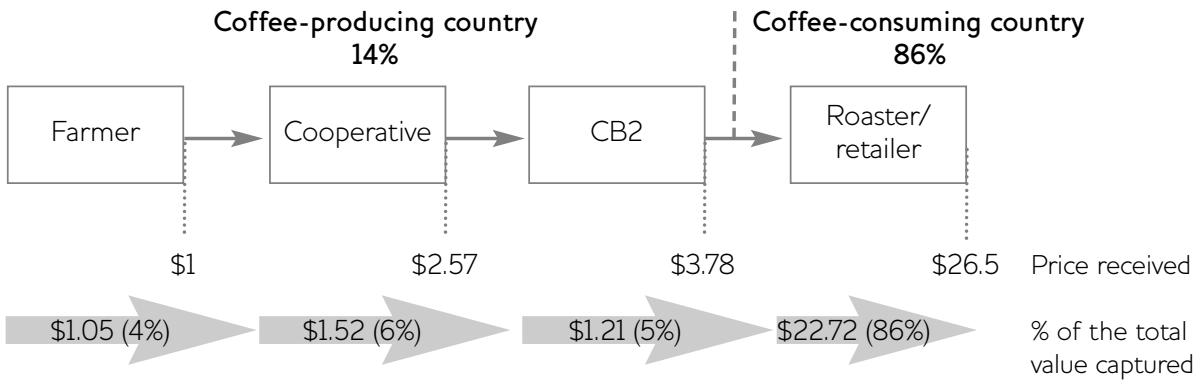




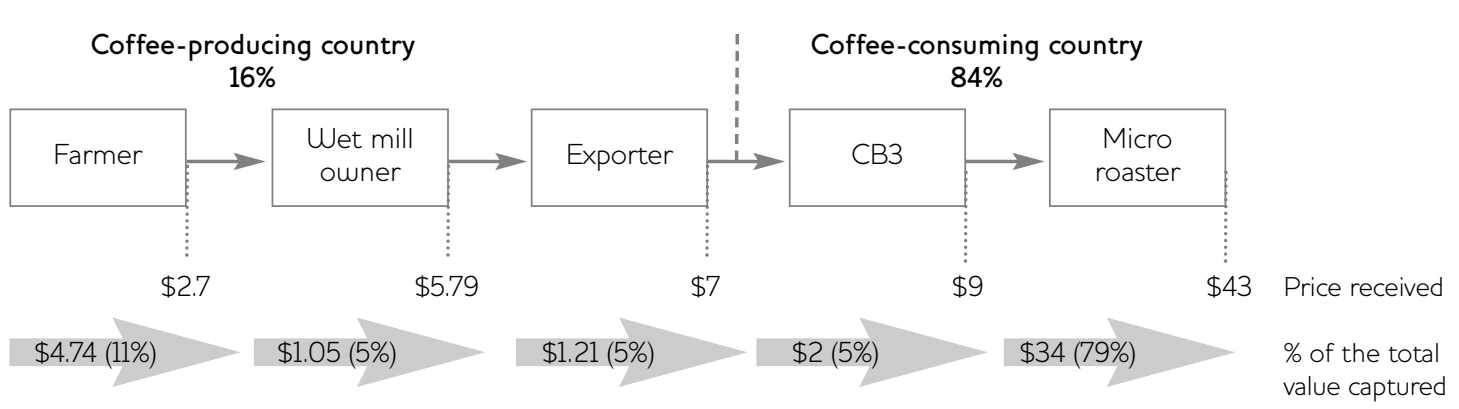

Source Authors' own.

would be interesting to improve it by adding the costs incurred by each actor, and by correcting the quantities with the application of the purchasing power parity principle.

With this analysis, we do not intend to establish any general conclusions about the distribution of value in direct trade chains in general or even in the supply chains managed by CB1, CB2 and CB3 in particular. We only had access to data about the value chains of three types of coffee in one specific moment in time, and we would like it to be taken as a first approach to the analysis of value distribution in these chains. Further research is needed to validate our initial findings.

\section{Conclusion}

The speciality coffee industry represents an opportunity for coffee producers. In this highvalue niche market, coffee becomes a product differentiated by quality, flavour, origin and even intangible attributes such as social and environmental sustainability. The final price is much higher and more stable; therefore producers can capture more value in a more reliable way. Furthermore, speciality coffee roasters seek to establish and develop long-term relationships with producers who are able to supply the coffee they want in a consistent way.

Smallholder farmers could benefit from this market segment, but in order to do so they need to grow and process high-quality coffee and have access to the appropriate marketing channels. 'Connective businesses' are BoP businesses that work with smallholder farmers in order to reduce the transactional and productivity constraints they face to access the speciality coffee market. Connective businesses operate on the basis of shared value creation. They connect farmers with speciality coffee roasters that otherwise would not be able to meet and work together in a direct trade relationship.

Our study suggests that smallholders' association with connective businesses is beneficial for both parties. The distribution of value in connective business supply chains is not essentially different from that of the mainstream ones, but the end value generated is much bigger, therefore smallholders capture significantly more value than in traditional markets. Besides, the advantages of this relationship should not only be valued by the economic gains, but also by direct market access and farmers' empowerment. Certainly, there are also risks involved: farmers might side-sell their production to a better bidder, damaging the relationship with the connective business, or they could become locked to one buyer who suddenly abandons the partnership. To avoid these risks that would ruin the shared value creation, contracts are essential, but all participants in this study agree that mutual commitment and trust are even more important.

Connective businesses are reaching smallholders of isolated coffee-producing regions in their search for speciality coffee varieties, and offering them training and access to the markets. Therefore, this could become a means for integrating vulnerable farmers into a differentiated market segment (even farmers that were marginalised in the sustainable certified coffee segment). Some governments, such as Rwanda, and development actors, such as Technoserve and SNV, have realised the opportunity speciality coffee represents for 
poverty alleviation and rural development in coffee regions, and they are beginning to collaborate with connective businesses and speciality coffee roasters. Nevertheless, it is worth noticing that not every producer can find its place in this market, which only represents around 10 per cent of the world consumption. And even the ones supplying high-quality coffee should not ignore the mainstream market but participate in both: speciality for their top quality and mainstream for the rest of their production.

\section{Notes}

1 One bag contains $60 \mathrm{~kg}$ of coffee.

2 Based on world consumption data and retail prices in calendar year 2012.

3 All coffee-growing countries fall into the lower-income and middle-income nations of the world in terms of annual average GNP per capita (Mutua 2000).

4 Between 2011 and 2013, the decline of prices made farmers sell their coffee at a loss, increasing farmers' vulnerability and rural poverty in coffee-producing regions (International Coffee Organization 2014b).

5 In 2013, leaf rust (la roya) decimated many coffee farms all over Central America. Farmers from this region are bringing less coffee to market, earning less for what they manage to produce, and having increasing costs due to investments in rust mitigation efforts. Experts state that coffee farming could even become unprofitable for smallholders in this region (World Coffee Research 2013).

6 Coffee consumption in emerging and exporting countries has been growing rapidly and shows potential for further growth. Traditional markets are growing modestly, but present dynamic niche opportunities such as speciality and certified coffees (International Coffee Organization 2014b).

7 A soft commodity refers to a commodity that is grown rather than mined or manufactured.

8 African farmers are disproportionately underrepresented as suppliers to sustainable markets (Potts et al. 2014) and smallholders from middle-income Latin American countries are usually unable to access certifications without the support of development actors.

9 National speciality coffee competitions that take place once a year.
The speciality coffee industry is reshaping the way coffee supply chains are managed and governed, demonstrating that another way of trading coffee is possible. Further research is needed to assess direct trade impacts on sustainability and development outcomes of coffee-producing regions, as well as the socioeconomic impacts connective businesses are generating for the livelihoods of smallholders.

10 Arabica coffee is priced against the New York ' $\mathrm{C}$ ' Market, a commodities exchange where coffee futures are bought and sold.

11 Free On Board (FOB) price means that the seller runs with the cost of transportation of goods to the port of shipment, plus the costs of loading them onto the vessel.

$12 \mathrm{CB} 1$ only trades coffee that scores 80 points or above on the 100-point scale of the Q-grading system (see http://coffeeinstitute.org/).

13 A certification for companies that wish to benefit society as well as their shareholders (see www.bcorporation.net/).

14 For example, many African smallholders are not regular coffee consumers, therefore they understand very little about the final product. In a quality training workshop held by $\mathrm{CB} 2$ in July 2013 in a rural area of Tanzania, two cups of coffee were given to farmers - one made from inferior quality beans and another from high-quality beans. Farmers were asked to choose the better tasting one. All the farmers chose the coffee made from inferior quality beans.

15 For example, a long-term supplier of some well-known American coffee roasters connected to the speciality coffee market by CB1 - suffered the effects of the Coffee Leaf Rust disease this past year, which decimated most of the farm. The farmer was unable to satisfy the contracted sales volume and did not have enough income to replant her dead trees. Instead of abandoning her, her longterm partners (for more than 20 years) initiated a crowdfunding campaign to raise money to save her farm, and it was successful. 16 CB2 estimates its investment in farmers' training to be US $\$ 50$ per farmer per year. 


\section{References}

Bolwig, S.; Ponte, S.; du Toit, A. and Halberg, N. (2010) 'Integrating Poverty and Environmental Concerns into Value-chain Analysis?: A Conceptual Framework', Development Policy Review 28.2: 173-94

Carter, C.R. and Easton, P.L. (2011) 'Sustainable Supply Chain Management: Evolution and Future Directions', International Journal of Physical Distribution and Logistics Management 41.1: 46-62

Clay, J.W. (2005) Exploring the Links Between International Business and Poverty Reduction: A Case Study of Unilever in Indonesia, Oxford, Den Haag and London: Oxfam GB, Novib Oxfam Netherlands and Unilever

Curtis, M. (2013) Powering Up Smallholder Farmers to Make Food Fair. A Five Point Agenda, (Fairtrade Foundation, ed.), London: Fairtrade Foundation

Drayton, B. and Budinich, V. (2010) 'A New Alliance for Global Change', Harvard Business Review 9: 56-64

Dries, L. and Swinnen, J.F.M. (2004) 'Foreign Direct Investment, Vertical Integration, and Local Suppliers: Evidence from the Polish Dairy Sector', World Development 32.9: 1525-44 du Toit, A. (2008) 'Living on the Margins: the Social Dynamics of Economic Marginalisation', Development Southern Africa 25.2: 135-50

Fitter, R. and Kaplinsky, R. (2001) 'Who Gains from Product Rents as the Coffee Market Becomes More Differentiated? A Value-chain Analysis', IDS Bulletin 32.3: 69-82

Gereffi, G. and Lee, J. (2012) 'Why the World Suddenly Cares About Global Supply Chains', Journal of Supply Chain Management 48.3: 24-32

Gibbon, P. (2001) 'Upgrading Primary Production: A Global Commodity Chain Approach', World Development 29.2: 345-63

Hall, J. and Matos, S. (2010) 'Incorporating Impoverished Communities in Sustainable Supply Chains', International Journal of Physical Distribution and Logistics Management 40.1/2: 124-47

International Coffee Organization (2014a) Coffee Market Report. September 2014, London:

International Coffee Organization: 1-6

International Coffee Organization (2014b) World Coffee Trade (1963-2013): A Review of the Markets, Challenges and Opportunities Facing the Sector, No ICG 111-5 Rev.1, London: International Coffee Organization: 1-29

International Trade Centre (2011) The Coffee Exporter's Guide, 3rd ed., Geneva: International Trade Centre
Karnani, A. (2011) Fighting Poverty Together:

Rethinking Strategies for Business, Governments, and Civil Society to Reduce Poverty, New York NY: Palgrave Macmillan

Karnani, A. (2007) 'Fortune at the Bottom of the Pyramid: A Mirage. How the Private Sector Can Help Alleviate Poverty', California Management Review 49.4: 90-111

Kilian, B.; Jones, C.; Pratt, L. and Villalobos, A. (2006) 'Is Sustainable Agriculture a Viable Strategy to Improve Farm Income in Central America? A Case Study on Coffee', Journal of Business Research 59.3: 322-30

London, T. (2008) 'The Base-of-the-Pyramid Perspective: A New Approach to Poverty Alleviation', in Proceedings of the Sixty-Sixth Annual Meeting of the Academy of Management, Washington DC: Academy of Management London, T. and Hart, S.L. (2004) 'Reinventing Strategies for Emerging Markets: Beyond the Transnational Model', Journal of International Business Studies 35.5: 350-70

London, T.; Anupindi, R. and Sheth, S. (2010) 'Creating Mutual Value: Lessons Learned from Ventures Serving Base of the Pyramid Producers', Journal of Business Research 63.6: 582-94

Mckone-Sweet, K.E. (2004) 'Lessons from a Coffee Supply Chain', Supply Chain Management Review 8.7: 52-9

Mendoza, R.U. and Thelen, N. (2008) 'Innovations to Make Markets More Inclusive for the Poor', Development Policy Review 26.4: 427-58

Minten, B.; Randrianarison, L. and Swinnen, J.F.M. (2009) 'Global Retail Chains and Poor Farmers: Evidence from Madagascar', World Development 37.11: 1728-41

Mutua, J. (2000) Post Harvest Handling and Processing of Coffee in African Countries, Rome: FAO, Agriculture and Consumer Protection Department

Panhuysen, S. and van Reenen, M. (2012) Coffee Barometer 2012, The Hague: Tropical Commodity Coalition

Ponte, S. (2002a) 'Brewing a Bitter Cup?

Deregulation, Quality and the

Re-organization of Coffee Marketing in East Africa', Journal of Agrarian Change 2.2: 248-72

Ponte, S. (2002b) 'The "Latte Revolution"?

Regulation, Markets and Consumption in the Global Coffee Chain', World Development 30.7: 1099-122

Porter, M.E. and Kramer, M.R. (2011) 'The Big Idea: Creating Shared Value', Harvard Business Review 89.1-2 
Potts, J.; Lynch, M.; Wilkings, A.; Huppé, G.; Cunningham, M. and Voora, V. (2014) The State of Sustainability Initiatives Review 2014: Standards and the Green Economy, Geneva: International Institute for Sustainable Development (IISD) and International Institute for Environment and Development (IIED)

Prahalad, C. (2005) The Fortune at the Bottom of the Pyramid, Upper Saddle River NJ: Wharton School Publishing

Prahalad, C. and Hammond, A. (2002) 'Serving the World's Poor, Profitably', Harvard Business Review 80.9

Prahalad, C. and Hart, S.L. (2002) 'The Fortune at the Bottom of the Pyramid', Strategy + Business, First Quarter 2002.26

Raynolds, L.T. (2009) 'Mainstreaming Fair Trade Coffee: From Partnership to Traceability', World Development 37.6: 1083-93
Reardon, T.; Codron, J.-M.; Busch, L.; Bingen, J. and Harris, C. (2001) 'Global Change in

Agrifood Grades and Standards: Agribusiness Strategic Responses', International Food and Agribusiness Management Review 23.3-4: 421-35

Sodhi, M.S. and Tang, C.S. (2011) 'Social Enterprises as Supply-Chain Enablers for the Poor', Socio-Economic Planning Sciences 45.4: 146-53

Speciality Coffee Association of America (2014) 'US Speciality Coffee Facts and Figures', December, www.scaa.org (accessed 15 December 2014)

Vachon, S. and Mao, Z. (2008) 'Linking Supply Chain Strength to Sustainable Development: A Country-level Analysis', Journal of Cleaner Production 16.15: 1552-60

World Coffee Research (2013) First International Rust Summit. Final Report, Guatemala City: World Coffee Research 